\title{
PROGRAM BAKTI KESEHATAN UNTUK LANSIA DI PANTI WERDHA KRISTEN HANA
}

\author{
Noer Saelan Tadjudin ${ }^{1}$, Ruth Brigitta Salim ${ }^{2}$ \\ ${ }^{1}$ Departemen Kesehatan Jiwa, Universitas Tarumanagara Jakarta \\ Email:noert@fk.untar.ac.id \\ ${ }^{2}$ Program Studi Pendidikan Dokter, Universitas Tarumanagara Jakarta \\ Email: ruthh.406202068@stu.untar.ac.id
}

\begin{abstract}
The aging process that is not avoided by the elderly. The elderly experience physical and mental decline and are vulnerable to the severity of the Covid-19 infection. Family and community participation is needed to pay attention to the needs of the elderly. The Christian Hana Nursing Home is a partner of the Faculty of Medicine, Tarumanagara University for the implementation of Geriatric clinical clerkship learning activities. During the pandemic, the Hana Christian Home Care carried out isolation for partner residents to prevent the transmission of the Covid-19 virus. Many residents are sad and feel that their families are not paying attention, and the elderly are a group that is vulnerable to the Covid-19 virus. Based on the problems that arose at the Hana Christian Nursing Home, we held a health service activity in the form of counseling about COVID-19 for the elderly. The health service activities that we carry out are needed because there is increased knowledge about COVID-19 for the elderly so that they can implement preventive measures against COVID-19 and stay happy during this pandemic. The health service activity which was attended by 70 elderly people was carried out on Saturday, September 4, 2021 at the Hana Christian Home Care Multipurpose Building, Pamulang. Health service activities are carried out still in the conditions of the Covid-19 pandemic and PPKM, health service activities follow the rules of the Hana Christian Home, comply with the COVID-19 health protocol, health service activities at the Multipurpose Building, health service participants watch live broadcasts in their respective rooms - each with a television connected to the health service program we do. Service participants participated in health service events accompanied by health counseling related to Covid-19 with enthusiasm and hoped that health service activities could take place continuously and collaborate with other.
\end{abstract}

Keywords: Elderly, counseling, health service

ABSTRAK
Proses penuaan menyebabkan lansia rentan terhadap penyakit. Lansia mengalami kemunduran secara fisik dan mental dan rentan terhadap keparahan akibat infeksi Covid-19. Peran serta keluarga serta masyarakat diperlukan untuk memperhatikan kebutuhan lansia. Panti Werdha Kristen Hana adalah mitra Fakultas Kedokteran Universitas Tarumanagara untuk terselenggaranya kegiatan pembelajaran kepaniteraan klinik Geriatri. Selama pandemi, Panti Werdha Kristen Hana melakukan isolasi bagi penghuni mitra guna mencegah penularan virus Covid-19. Penghuni banyak yang sedih serta merasa tidak diperhatikan keluarganya, serta lansia adalah golongan yang rentan terhadap virus Covid-19. Berdasarkan permasalahan yang timbul pada Panti Werdha Kristen Hana maka kami mengadakan kegiatan bakti kesehatan berupa penyuluhan tentang COVID-19 pada lansia. Kegiatan bakti kesehatan yang pengabdian lakukan diperlukan karena bertambah pengetahuan mengenai COVID-19 bagi para lansia sehingga mereka dapat menerapkan upaya pencegahan terhadap COVID-19 dan tetap bahagia selama masa pandemi ini berlangsung. Kegiatan bakti kesehatan yang diikuti 70 lansia dilakukan pada hari Sabtu, 4 September 2021 di Gedung Serba Guna Panti Werdha Kristen Hana, Pamulang telah terlaksana dengan baik. Kegiatan bakti kesehatan dilakukan masih dalam kondisi pandemi Covid-19 dan PPKM, kegiatan bakti kesehatan mengikuti peraturan dari Panti Werdha Kristen Hana, mematuhi protokol kesehatan COVID-19 maka kegiatan bakti kesehatan di Gedung Serba Guna, peserta bakti kesehatan menonton siaran secara live di kamar masing- masing dengan televisi yang terhubung dengan acara bakti kesehatan yang tim pengabdian lakukan. Peserta pengabdian mengikuti acara bakti kesehatan yang disertai penyuluhan kesehatan terkait Covid-19 dengan antusias serta mengharapkan agar kegiatan bakti kesehatan dapat berlangsung secara kontinu serta berkolaborasi dengan pihak lain.

Kata kunci: Lansia, penyuluhan, bakti kesehatan 


\section{PENDAHULUAN}

Setiap manusia pasti akan mengalami proses penuaan dan pada akhirnya menjadi orang lanjut usia atau yang biasa disebut lansia. Menurut Undang-Undang Republik Indonesia No. 13 tahun 1998, lansia adalah seseorang yang telah memasuki usia 60 tahun ke atas. (Tursina A, 2020).

Di era pandemi Covid -19 yang sudah dua tahun dialami maka terjadi kondisi peningkatan umur harapan hidup serta lonjakan peningkatan jumlah lansia. Pada tahun 2019 jumlah lansia sebanyak 25,9 juta jiwa (9,7\%), jumlah ini meningkat apabila dibandingkan tahun 2010 jumlah lansianya sebesar 18 juta jiwa (7,56\%). Jumlah lansia diprediksi terus bertambah banyak bisa mencapai 48,2 juta jiwa di tahun 2035 (15,77\%). Melihat peningkatan jumlah lansia dari tahun ke tahun maka Indonesia dikategorikan pada tahap aging population. (Kemenkes,2019)

Lansia lebih rentan menderita COVID-19 karena imunitas tubuh lansia mengalami penurunan seiring berjalannya waktu. Selain itu apabila lansia terkena COVID-19, gejala klinis dan komplikasi yang dialaminya lebih berat dibandingkan orang muda. Proses penyembuhan pada lansia lebih lama dan juga terdapat gejala sisa. (Bajaj,2021)

Proses penuaan yang terjadi pada lansia merupakan proses fisiologi, tetapi proses penuaan ini membuat lansia mengalami kemunduran secara struktur maupun fungsi organ. Pada proses penuaan lansia tubuhnya tidak tahan terhadap paparan infeksi serta kerusakan yang berat, karena kemampuan jaringan tubuh untuk memperbaiki atau menggantikan dengan yang baru sudah mengalami hendaya sehingga lansia mengalami kemunduran baik secara mental maupun fisik. (Kemenkes,2018).

Dampak akibat terjadi isolasi sosial yang dilakukan pada lansia terutama di panti werdha ternyata memberikan dampak buruk bagi kesehatan mental penghuni panti Werdha. Hambatan yang dialami lansia tidak bisa berinteraksi dengan keluarga serta menimbulkan stress dan depresi. Kondisi stress dan depresi pada lansia sebaiknya dihindari karena mempengaruhi imunitas dari lansia. Jika sistem imun lansia kurang baik maka beresiko tinggi apabila terkena infeksi virus Covid-19. (Armitage and Nellums, 2020).

Panti Werdha Kristen Hana berlokasi di Jalan H. Taip No. 52 Kedaung - Pamulang, Tangerang 1541, tujuan pembentukkan panti Werdha Kristen Hana yang merupakan bagian dari Badan Pelayanan milik Gereja Kristen Indonesia Sinode Wilayah Jawa Barat adalah memberikan pelayanan kepada lanjut usia agar lanjut usia dapat menikmati kehidupannya dengan sehat dan sejahtera. Pada tanggal 2 Maret 2020 kasus Covid-19 di Indonesia sudah diumumkan pemerintah, maka Panti Werdha Kristen Hana melakukan tindakan untuk mengantisipasi penyebaran virus Covid-19 dengan melakukan serta menerapkan protokol kesehatan di Panti Werdha seperti mewajibkan memakai masker secara tertur, menjaga jarak antar peserta panti danpetugas panti, mencuci tangan dengan air mengalir serta sabun. Panti Werdha Kristen Hana membatasi aktivitas kerumunan di daerah sekitar panti Werdha Kristen Hana, kunjungan keluarga serta kegiatan sosial yang biasa dilakukan untuk menghibur peserta panti ditiadakan aktivitasnya. (Yayasan Panti Werdha Hana,2021)

Panti Werdha Kristen Hana adalah mitra Fakultas Kedokteran Universitas Tarumanagara untuk terselenggaranya kegiatan pembelajaran kepaniteraan klinik Geriatri. Selama pandemi, panti werdha Kristen Hana melakukan isolasi bagi penghuni mitra guna mencegah penularan virus Covid-19. Sebagian besar penghuni merasa sedih serta tidak diperhatikan keluarganya, serta lansia adalah golongan yang rentan terhadap virus Covid-19. Berdasarkan permasalahan yang timbul pada Panti Werdha Kristen Hana maka kami mengadakan kegiatan bakti kesehatan berupa penyuluhan tentang COVID-19 pada lansia. Kegiatan bakti kesehatan yang tim pengabdian lakukan diperlukan karena bertambah pengetahuan mengenai COVID-19 bagi para lansia sehingga mereka dapat menerapkan upaya-upaya pencegahan terhadap COVID-19 dan tetap bahagia selama masa pandemi ini berlangsung. 


\section{METODE PELAKSANAAN}

Metode bakti kesehatan di Panti Werdha Kristen Hana dilakukan dengan penyuluhan tentang edukasi mengenai Covid-19, cara pencegahan serta vaksinasi Covid-19. Rangkaian persiapan kegiatan bakti kesehatan pemeliputi :

1. Sosialisasi : tim pengabdian melakukan pertemuan dengan Pimpinan/kepala Panti Werdha Kristen Hana dan petugas Panti . Pada pertemuan ini tim pengabdian menyampaikan bentuk pelaksanaan serta materi yang akan disampaikan di bakti kesehatan.

2. Perumusan solusi : Hasil dari pertemuan dengan pimpinan Panti Werdha Kristen Hana ditetapkan tanggal pelaksanaan kegiatan 4 September 2021. Acara tidak boleh dilakukan bertemu langsung dengan penghuni Panti Werdha Kristen Hana. Solusi yang telah didiskusi tim pengabdian yaitu kegiatan akan berlangsung live di Gedung serbaguna di Panti Werdha Kristen Hana, penghuni panti dapat mengikuti acara bakti kesehatan dengan menonton TV di kamar masing-masing yang terhubung dengan kegiatan bakti kesehatan.

3. Penyuluhan kesehatan pada lansia dengan materi meliputi upaya-upaya pencegahan terhadap COVID-19 mengingat beratnya efek COVID-19 terhadap lansia serta menjaga kesehatan mental lansia selama masa pandemi, selain acara penyuluhan, tim pengabdian juga menyertakan acara hiburan yang dapat menghibur peserta panti serta meningkatkan kesehatan mental lansia di Panti Werdha Kristen Hana.

\section{HASIL DAN PEMBAHASAN}

Kegiatan bakti kesehatan ini dilakukan pada hari Sabtu, 4 September 2021 di Gedung Serba Guna Panti Werdha Kristen Hana, Pamulang. Saat pelaksanaan kegiatan bakti kesehatan dilakukan masih dalam kondisi pandemi Covid-19 dan PPKM, maka tim pengabdian melaksanakan kegiatan bakti kesehatan mengikuti peraturan dari Panti Werdha Kristen Hana dan semua kegiatan kegiatan mematuhi protokol kesehatan COVID-19. Pihak panti Werdha Kristen Hana melarang para opa dan oma untuk bertemu secara langsung dengan Tim pengabdian, namun, hal tersebut bukanlah suatu halangan bagi tim pengabdian untuk melakukan kegiatan bakti kesehatan. Kegiatan bakti kesehatan dilaksanakan di Gedung Serba Guna sedangkan opa oma menonton siaran kegiatan pengabdian secara live di kamar masing- masing dengan televisi yang terhubung dengan acara bakti kesehatan.

Susunan acara kegiatan bakti kesehatan sebagai berikut :

\begin{tabular}{ll}
\hline $10.00-10.05$ & Perkenalan singkat \\
\hline $10.05-10.10$ & Kata sambutan dari Dr. dr. Noer Saelan Tadjudin selaku dekan FK Untar \\
\hline $10.10-10.15$ & Persembahan lagu dari Oma Mintarsih berkolaborasi dengan dokter muda \\
\hline $10.15-10.30$ & Pemaparan materi COVID \\
\hline $10.30-10.35$ & Persembahan lagu dari dokter muda \\
\hline $10.35-10.40$ & Serah terima tanda kasih dari FK Untar kepada pihak Panti Werdha Kristen Hana \\
\hline 10.40 - selesai & Penutup \& Ucapan terima kasih \\
\hline
\end{tabular}

Ide kegiatan pengabdian terkait bakti Kesehatan di Panti Werdha Kristen Hana diprakasai oleh Dekan Fakultas Kedokteran Universitas Tarumanagara, beserta Tim dokter muda yang terdiri dari

1. Ruth Brigitta Salim selaku MC dan pemain harpa

2. Nathania Hadasa Tamar selaku MC dan penyanyi

3. Pricillia Christianingsih selaku tim penyuluhan

4. Rayhan Alghifari Iridansyah Siregar selaku tim penyuluhan 
5. Natasya selaku tim penyuluhan

6. Erpinna Lamria Siagian

7. Claudia Agnes Jap

8. Eric

9. Paulina Selvilla

10. Yusuf Damar Jatinugroho

Pemandu Acara membuka acara kegiatan serta memperkenalkan Dekan FK UNTAR serta anggota Tim pengabdian, acara dilanjutkan dengan kata sambutan dari Dr. dr. Noer Saelan Tadjudin, Sp.KJ selaku Dekan Fakultas Kedokteran Universitas Tarumanagara. Untuk menciptakan suasana damai bagi opa dan oma yang menonton acara pengabdian maka tim pengabdian mempersembahan lagu "Bapa Engkau Sungguh Baik" yang dibawakan oleh Ruth Brigitta Salim bermain harpa dan Nathania Hadasa sebagai penyanyi, pada kesempatan ini tim pengabdian berkolaborasi dengan Oma Mintarsih, salah satu oma di Panti Werdha Kristen Hana. Untuk acara kegiatan bakti kesehatan selanjutnya maka tim penyuluhan memaparkan materi mengenai COVID-19, mulai dari pencegahan hingga pentingnya menjaga kesehatan mental khususnya bagi lansia, setelah mendengarkan pemaparan materi dari tim penyuluh maka acara dilanjutkan dengan persembahan lagu "Kusiapkan Hatiku" dan "Waktu Tuhan" oleh Ruth Brigitta Salim (harpa) dan Nathania Hadasa Tamar (nyanyi) untuk menghibur para oma dan opa di Panti Werdha Kristen Hana. Tim pengabdian memberikan donasi berupa dua pak pampers isi 30 buah berukuran XL kepada Panti Werdha Hana sebagai bentuk cinta kasih kami kepada oma opa di sana. Pampers ini secara simbolis diberikan oleh Dr. dr. Noer Saelan Tadjudin kepada pihak panti asuhan. Pihak panti merasa senang atas terselenggaranya kegiatan bakti kesehatan ini.
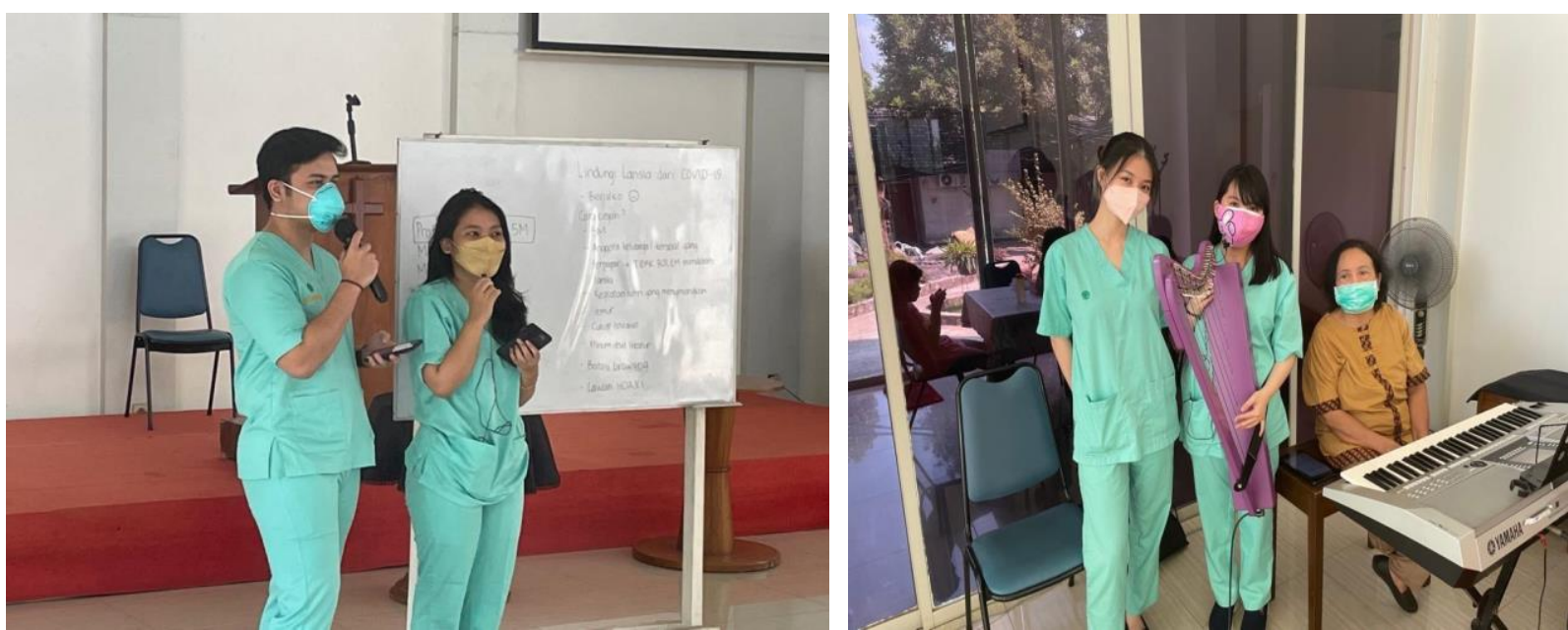

Gambar 1. Acara kegiatan bakti kesehatan (perkenalan)

Kegiatan bakti kesehatan yang dilakukan pada lansia di Panti Werdha Kristen Hana bermaksud untuk melakukan pemeliharaan kesehatan geriatri yang mencakup tindakan promotif dan preventif. Sasaran kegiatan ini adalah penghuni Panti Werdha Kristen Hana dan staff Panti Werdha Kristen Hana. Panti Werdha Kristen Hana adalah salah satu mitra dari Fakultas Kedokteran Universitas Tarumanagara untuk melaksanakan kepaniteraan klinik Geriatri serta tim pengabdian ingin meningkatkan kepedulian dan tanggung jawab untuk tetap melaksanakan kegiatan pengabdian masyarakat dan menerapkan keilmuwan yang tim pengabdian miliki agar bermanfaat bagi peserta Werdha Kristen Hana. Manfaat yang didapat dari kegiatan bakti kesehatan adalah bertambahnya wawasan serta kesadaran dari pihak panti serta lansia di Panti 
Werdha Kristen Hana untuk menerapkan upaya-upaya pencegahan terhadap COVID-19 mengingat beratnya efek COVID-19 terhadap lansia.

Keterbatasan informasi serta lansia mengalami kesulitan memahami informasi virus Covid-19 maka penyuluhan terkait Covid-19 tepat dilakukan diPanti Werdha Kristen Hana. Penyuluhan merupakan suatu bentuk pendidikan kesehatan untuk mengubah prilaku serta menciptakan kesadaran bagi peserta penyuluhan untuk peduli menjaga kesehatan dirinya serta mencegah dari keadaan yang dapat menimbulkan penyakit. Penyuluhan yang tim pengabdian lakukan merupakan cara edukasi kesehatan yang dapat diterima dengan mudah, cepat serta efektif ke peserta bakti kesehatan masyarakat. Penyuluhan dengan materi Covid-91 adalah langah promotif dan preventif bagi peserta penyuluhan untuk meningkatkan derajat kesehatan. Peserta bakti kesehatan terdiri dari lansia berusia 65-90 tahun merupakan peserta yang beresiko tinggi serta berakibat fatal apabila terinfeksi virus Covid-19 sehingga dengan adanya penyampaian informasi yang tepat melalui penyuluhan lansia di Panti Werdha Kristen Hana dapat terhindar dari paparan virus Covid-19 serta menerapkan pola hidup sehat.(Notoadmojo,2012), (Wahyu,2020)

Kegiatan bakti kesehatan yang diikuti 70 lansia yang tinggal di Panti Werdha Kristen Hana merupakan bentuk kepedulian dan tanggung jawab untuk tetap melaksanakan kegiatan pengabdian masyarakat dan menerapkan keilmuwan yang tim pengabdian miliki agar bermanfaat bagi peserta Werdha Kristen Hana. Kegiatan penyuluhan kesehatan disertai acara rekreasi berdampak bagi kesehatan mental karena kegiatan pengabdian merupakan salah satu cara untuk menghilangkan rasa ketidaknyaman serta perasaan kesepian yang dialami pada opa dan oma Panti Werdha Kristen Hana selama masa pandemi. (CDC,2020)

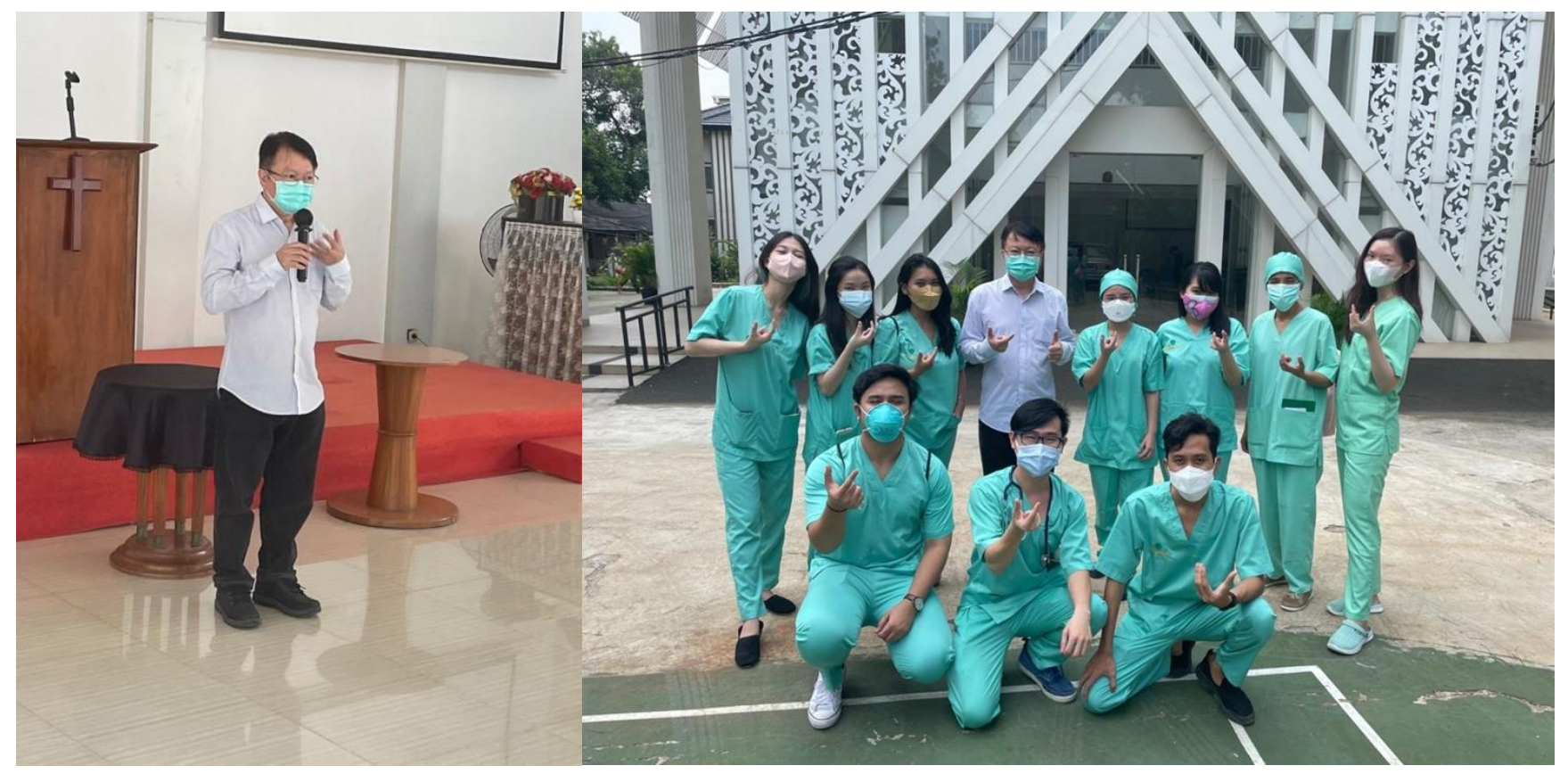

Gambar 2. Acara kegiatan bakti kesehatan

Kegiatan bakti kesehatan yang tim pengabdian lakukan kepada lansia di Panti Werdha Kristen Hana merupakan perwujudan untuk menjalankan salah satu poin tridharma pada perguruan tinggi. Pihak panti, opa dan oma yang tinggal di panti Werdha Kristen Hana memberikan tanggapan positif terhadap keseluruhan acara bakti kesehatan. Opa dan oma semua terhibur dan merasa diperhatikan dengan berlangsungnya kegiatan bakti kesehatan ini, karena berdasarkan 
wawancara dengan pihak panti selama pandemi Covid-19 yang hampir berlangsung 2 tahun pihak panti melarang kunjungan dari pihak keluarga sehingga opa dan oma merasa kesepian dan hal ini berdampak pada mental mereka seperti stress, sedih. Acara bakti kesehatan berjalan dengan baik dan tanpa kendala, pihak panti Werdha Kristen Hana mengharapkan agar kegiatan bentuk ini untuk lebih sering dilakukan oleh pihak Fakultas Kedokteran Universitas Tarumangara dengan materi yang berbeda, sehingga peserta panti Werdha Kristen Hana selain terhibur juga bertambah wawasan terkait menjaga kesehatan selama pandemi Covid-19.

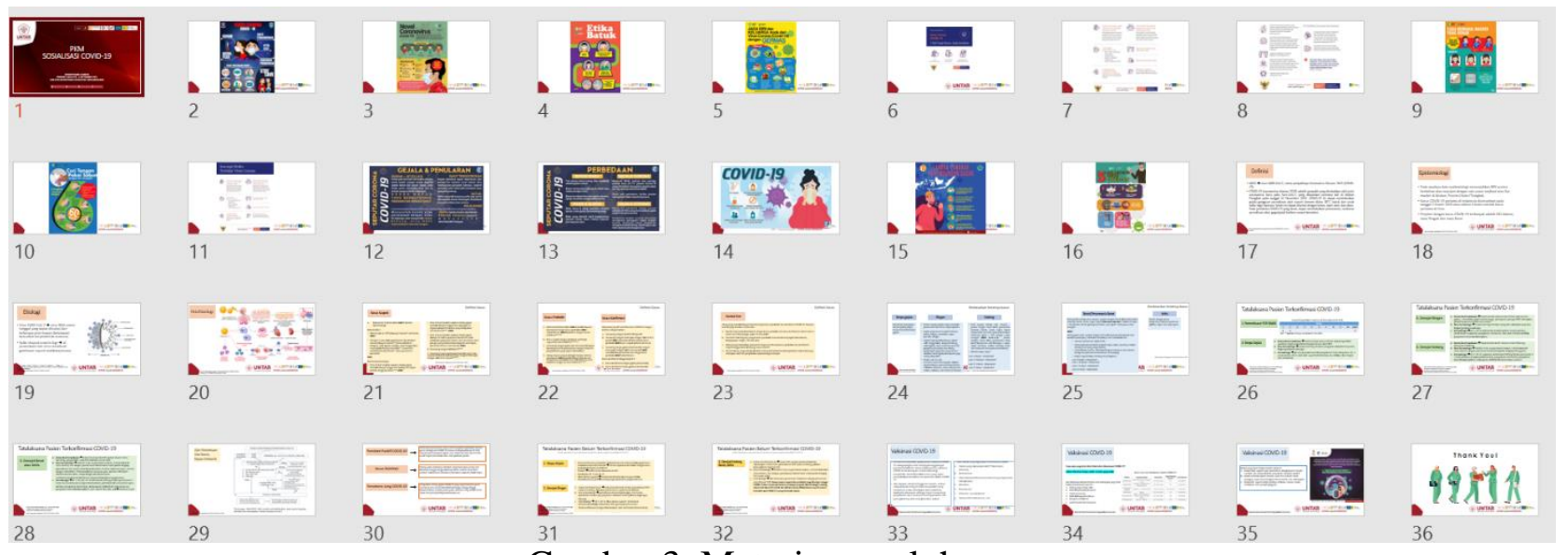

Gambar 3. Materi penyuluhan

\section{KESIMPULAN DAN SARAN}

Kegiatan bakti kesehatan yang diikuti 70 lansia dilakukan pada hari Sabtu, 4 September 2021 di Gedung Serba Guna Panti Werdha Kristen Hana, Pamulang telah terlaksana dengan baik. Kegiatan bakti kesehatan dilakukan masih dalam kondisi pandemi Covid-19 dan PPKM, kegiatan bakti kesehatan mengikuti peraturan dari Panti Werdha Kristen Hana, mematuhi protokol kesehatan COVID-19 maka kegiatan bakti kesehatan di Gedung Serba Guna, peserta bakti kesehatan menonton siaran secara live di kamar masing- masing dengan televisi yang terhubung dengan acara bakti kesehatan. Peserta pengabdian mengikuti acara bakti kesehatan yang disertai penyuluhan kesehatan terkait Covid-19 dengan antusias serta mengharapkan agar kegiatan bakti kesehatan dapat berlangsung secara kontinu serta berkolaborasi dengan pihak lain.

\section{Ucapan Terima Kasih (Acknowledgement)}

Ucapan terima kasih penulis sampaikan kepada PANTI WERDHA KRISTEN HANA atas dukungannya, kepada seluruh panitia acara dan peserta yang telah mengikuti kegiatan bakti kesehatan ini, sehingga kegiatan dapat terlaksana dengan baik dan lancar. Terima kasih juga kepada Panitia SENAPENMAS yang sudah memberikan kesempatan untuk berpatisipasi pada kegiatan SENAPENMAS 2021

\section{REFERENSI}

Armitage, R., \& Nellums, L. B. (2020). COVID-19 and the consequences of isolating the elderly. The Lancet Public Health, 5(5), e256. https://doi.org/10.1016/S24682667(20)30061-X

Bajaj V, Gadi N, Spihlman A, Wu S, Choi C, Moulton V. (2021). Aging, Immunity, and COVID- 19: How Age Influences the Host Immune Response to Coronavirus Infections. Front Physiol. 2021; 11: 571416.

Center for Disease Control and Prevention (CDC) (2020). Coronavirus 2019 (COVID-19) Stress 


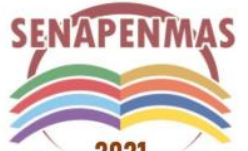

2021
Seminar Nasional Hasil Penelitian dan Pengabdian Kepada Masyarakat 2021 Pengembangan Ekonomi Bangsa Melalui Inovasi Digital Hasil Penelitian dan Pengabdian Kepada Masyarakat Jakarta, 21 Oktober 2021

and coping. https://www.cdc.gov/mentalhealth/stress-coping/cope-with-stress/index.html

Kemenkes.

(2018).

Hindari

Lansia

Dari

Covid19.

www.padk.kemkes.go.id/article/read/2020/04/23/21/hindari-lansia-dari-covid-19.html

Kemenkes. (2019). Indonesia Masuki Periode Aging Population. https://www.kemkes.go.id/article/view/19070500004/indonesia-masuki-periode-agingpopulation.html

Notoatmodjo (2012). Kesehatan Masyarakat Ilmu dan Seni. Jakarta, Rineka Cipta

Tursina A. (2020). COVID-19 dan Lansia. In: Respati T, Rathomi H. Editor. Kopid Pedia. Bandung: Pusat Penerbitan Universitas (P2U) Unisba

Wahyu. (2020). Lansia dan Pemahaman Protokol Kesehatan di Masa COVID-19. http://lipi.go.id/publikasi/lansia-dan-pemahaman-protokol-kesehatan-di-masa-covid$19 / 39485$

Yayasan Panti Werdha Hana.(2021). Profil Panti Werdha Hana. https://www.pwkhana.com/ 
Seminar Nasional Hasil Penelitian dan Pengabdian Kepada Masyarakat 2021

Pengembangan Ekonomi Bangsa Melalui Inovasi Digital Hasil Penelitian dan

Pengabdian Kepada Masyarakat

Jakarta, 21 Oktober 2021

(halaman kosong) 